\title{
Nitric oxide and related vasodilators
}

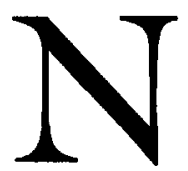

ITRIC oxide gas was first described in 1648 , and its chemical properties initially characterised in 1772 by Joseph Priestley, ${ }^{1}$ who called the gas "nitrous air" and described the reaction with "common air" to form nitrogen dioxide. A considerable amount of research has since been undertaken into the chemistry of nitric oxide because it is both central to industrial chemical processes such as nitric acid production and is an important environmental pollutant. Biological scientists have also long been interested in nitric oxide, it is a by-product of microbial metabolism and combines avidly with metalloproteins such as haemoglobin. ${ }^{2}$ Accidental exposure of humans to gaseous nitric oxide has occurred in industry, mining and agriculture, but anaesthetists are most familiar with two cases where inhaled nitric oxide and nitrogen dioxide were given to patients in high concentrations in 1966 as a result of contaminated nitrous oxide supplies. ${ }^{3}$ The first use for gaseous nitric oxide in medicine was as an alternative to carbon monoxide in the measurement of lung diffusing capacity, ${ }^{4}$ because it has considerably faster reaction kinetics with haemoglobin and so gives a better measurement of "true" lung diffusing capacity.

The discovery of endogenous nitric oxide production began with an observation by Furchgott and Zawadzki ${ }^{5}$ that vascular rings pre-constricted with noradrenaline relaxed when treated with acetylcholine only if they had intact vascular endothelium. This implied that acetylcholine triggered the release of a factor from the endothelium which diffused into the smooth muscle cells and caused smooth muscle relaxation. This substance was named EDRF (endothelium derived relaxing factor), and was a very short-lived molecule in biological systems. Although the vasodilator action of gaseous nitric oxide had been known for some time, ${ }^{6}$ it was not until 1987 that two groups independently showed that EDRF and nitric oxide were the same substance. ${ }^{7,8}$ Since then, there has been an explosion of research into nitric oxide, the number of references to nitric oxide has risen logarithmically over the last nine years. Nitric oxide is now implicated in vascular control, neurotransmission, immune function, reperfusion injury, and a host of other areas.

\section{Mechanism of action}

Nitric oxide is a highly diffusible, lipophilic molecule. When released from endothelial cells it passes to the underlying smooth muscle cells, and binds to the haem group of guanylyl cyclase, stimulating the conversion of cGTP (cyclic guanosine triphosphate) to cGMP (cyclic guanosine monophosphate). This reduces intracellular calcium by modulating calcium channel activity and calcium release from the sarcoplasmic reticulum, causing smooth muscle relaxation ${ }^{9}$ and hence vasodilatation. Nitric oxide is produced from $\mathrm{L}$-arginine and molecular oxygen by a family of enzymes called nitric oxide synthases (NOS), which are structurally similar to cytochrome P450 enzymes. There are two constitutive forms which produce a basal nitric oxide output in endothelial and other cells (ecNOS and ncNOS or simply cNOS), and a form which is only expressed after cells have been stimulated with cytokines, the inducible isoform (iNOS). The constitutive enzymes are important for regulation of basal vascular tone, the inducible isoform may have an antimicrobial function, and excess nitric oxide produced by this enzyme may account for the vasodilatation seen in septic shock.

Humans produce about $\mathrm{l} \mathrm{mM}$ of nitric oxide metabolites per day. Most of this nitric oxide probably arises from a continuous release from endothelial cells, and so modulates the pulmonary and systemic vascular resistances. This probably represents a local control mechanism. As flow through an artery increases, the shear stress on the vessel wall increases. This is a potent stimulus to nitric oxide production, which vasodilates the vessel to accommodate the increased flow. ${ }^{9}$ This may be particularly important in the coronary circulation, ${ }^{10}$ where the coronary blood flow can change greatly over a short period of time. Nitric oxide may also work in concert with endothelin, a powerful, endothelium-derived vasoconstrictor. Increased cGMP, an effect of nitric oxide activation of guanylyl cyclase, causes decreased endothelin synthesis, and hence further vasodilatation. ${ }^{11}$ Aggregating platelets release nitric oxide and prostacyclin, which has two major effects. Both of these mediators inhibit further platelet aggregation and also cause local vasodilatation, increasing

From the Nuffield Department of Anaesthetics, Radcliffe Infirmary Woodstock Road, Oxford OX2 6HE, United Kingdom.

Phone: (0)1865 224772; Fax: (0)1865 794191; E-mail: duncan.young@nda.ox.ac.uk 
local blood flow. ${ }^{12}$ This negative feedback control may represent one mechanism to prevent intravascular thromboses.

Nitric oxide is also a neurotransmitter, produced by the post synaptic neurone when glutamate receptors are activated. ${ }^{13}$ This has both central and peripheral effects. Nitric oxide is almost certainly the neurotransmitter of the NANC (non-adrenergic non-cholinergic) nervous system, which supplies abdominal viscera, airways, and other organs. Nitric oxide is also a neurotransmitter in the central nervous system, and might be important in memory and the linking of neuronal activity to local cerebral blood flow ${ }^{14,15}$ although this is as yet not proven.

Why mammals have an inducible, cytokine-activated nitric oxide synthase is uncertain, but it may help with host defence mechanisms. High output nitric oxide production by iNOS has been shown to be cytotoxic to large number of intracellular pathogens. ${ }^{16}$ The concentrations of nitric oxide produced may not be sufficiently high to be cytotoxic, but the product of superoxide and nitric oxide, peroxynitrite, may have a greater cytotoxic effect. Whether this effect is of clinical relevance in humans is unclear. ${ }^{17,18}$ Many other cytotoxic species are also produced by macrophages including the hypochlorite ion and hydroxyl radicals. Although levels of nitric oxide increase in human sepsis, this increase is nowhere near as dramatic as that seen in infected rodents. ${ }^{19}$

\section{Clinical use of gaseous nitric oxide}

The first report of gaseous nitric oxide being used as a pulmonary vasodilator was published by Pepke-Zaba $e t$ al. in $1991 .{ }^{20}$ They studied eight patients with severe pulmonary hypertension. Inhaling 40 parts per million (ppm) nitric oxide reduced the pulmonary vascular resistance in all of these patients, from about 1120 dynes. $\mathrm{sec} \cdot \mathrm{cm}^{-5}$ to about 800 dynes.sec. $\mathrm{cm}^{-5}$ (normal $<150$ dynes $\cdot \mathrm{sec} \cdot \mathrm{cm}^{-5}$ ). A similar reduction could be achieved with prostacyclin infusion in six of the eight patients, but this also caused a reduction in systemic vascular resistance from about 1900 dynes.sec. $\mathrm{cm}^{-5}$ to 1500 dynes $\cdot \mathrm{sec} \cdot \mathrm{cm}^{-5}$ (normal range 1000-2000). They concluded that inhaled nitric oxide was a selective pulmonary vasodilator. The nitric oxide acts on the ablumenal (outer) surface of pulmonary resistance vessels, causing vasodilatation. Any nitric oxide entering the circulation is immediately inactivated, reacting with oxyhaemoglobin to form methaemoglobin and inorganic nitrate. As inorganic nitrate (as opposed to organic nitrates) is not vasoactive, there are no direct systemic effects. Similar results were obtained in patients with pulmonary hypertension due to mitral valve disease ${ }^{21,22}$ and congenital heart disease. ${ }^{23,24}$ In all of these studies there was a statistically significant reduction in pulmonary vascular resistance, but in clinical terms the reduction was modest and the vascular resistance was still markedly raised during nitric oxide inhalation. This is in contrast to studies on volunteers where hypoxia was used to induce pulmonary hypertension, ${ }^{25}$ where nitric oxide totally reversed the hypoxic pulmonary vasoconstriction. Inhalation of nitric oxide has no effect on normal pulmonary vasculature. These results are as expected, acute pulmonary vasoconstriction is due to smooth muscle contraction, in hypoxia this is probably triggered by changes in the redox state of the cells which indirectly alters intracellular calcium levels. ${ }^{26}$ The effects of nitric oxide on intracellular calcium reverse this effect. In chronic pulmonary hypertension most of the increase in pulmonary vascular resistance is due to non-distensible matrix protein deposition in the adventitia, which is not affected by any vasodilators.

In foetal life the pulmonary vascular resistance is high, due to pulmonary vasoconstriction. This leads to high pressures on the right side of the circulation, which favours right-to-left shunting of blood via the foramen ovale and ductus arteriosus. After birth the pulmonary vascular resistance decreases dramatically, and the foramen ovale closes as left atrial pressures exceed the right atrial pressures. The ductus arteriosus also closes, and right to left shunting is abolished. However, in a few babies this decrease in pulmonary vascular resistance does not occur (persistent pulmonary hypertension of the new-born or PPHN). These babies have persisting right to left shunts, hypoxaemia, and are very difficult to treat. As the shunt increases the associated acidosis and hypoxia, it tends to prevent ductal closure and increase pulmonary vascular resistance. This in turn worsens the shunting. The ideal therapeutic agent in these circumstances would be a selective pulmonary vasodilator, as left sided pressures have to be maintained while right sided pressures are reduced. In the same issue of the Lancet in 1992 two groups published reports of the use of nitric oxide in these babies. 27,28 This had a dramatic effect on arterial oxygenation, the $\mathrm{PaO}_{2}$ increased between three and five-fold. There is now (as yet unpublished) evidence from a large randomized controlled trial (NINOS study) that inhaled nitric oxide in the patients reduces the requirement for extra-corporeal membrane oxygenation (ECMO) in these babies.

If nitric oxide is added to the inhaled gas of patients, whose lungs are mechanically ventilated for acute respiratory failure, a reduction in pulmonary vascular resistance can be demonstrated. However, the more striking change is an immediate increase in arterial oxygenation. 
The first report of this in a series of patients by Rossaint et al. ${ }^{29}$ showed an average improvement of $47 \mathrm{mmHg}$ $(6.2 \mathrm{kPa})$ in the $\mathrm{PaO}_{2} / \mathrm{FIO}_{2}$ ratio, and a $4 \%$ reduction in the shunt fraction. Simultaneous measurements using the multiple inert gas elimination technique (MIGET) showed this improvement was due to an improvement in ventilation/perfusion relationships. The usual explanation for this effect is that nitric oxide only reaches ventilated areas of the lung, and so selectively improves perfusion in well ventilated areas at the expense of poorly ventilated regions. This improves the matching of blood flow to ventilation. If a vasoconstrictor is given systemically at the same time, the poorly ventilated areas will vasoconstrict more, but the nitric oxide will antagonize the vasoconstriction in well ventilated areas and the effect on oxygenation will be additive. ${ }^{30}$ The reverse occurs when systemically administered vasodilators are given to patients with acute respiratory failure. The normal hypoxic pulmonary vasoconstriction that occurs in poorly ventilated regions is antagonized, and ventilation/perfusion matching worsens. ${ }^{31,32}$ This result has led to the adoption of nitric oxide as a treatment for ARDS in many countries, in spite of the fact that there are as yet no randomized trials showing any benefit beyond an improvement in arterial oxygenation.

\section{Nitric oxide donors}

There are at least 30 classes of nitric oxide donor compounds, of which only two (organic nitrates and sodium nitroprusside, an iron nitrosyl) are in common clinical use.

\section{Nitroglycerin}

Nitroglycerin was first synthesised in 1846, and the first use of sublingual nitroglycerin (glyceryl trinitrate, GTN) for angina was reported by Murrell in 1879.33 He had deduced that it might have a similar action to inhaled amyl nitrite, a substance shown to be anti-anginal by Brunton in 1857. Since that time GTN has been the mainstay of anti-anginal therapy, although isosorbide dinitrate, isosobide-5-mononitrate and erythrityl tetranitrate have been introduced to provide drugs with a longer duration of action for prophylaxis.

All these drugs are polyol esters of nitric acid (commonly called organic nitrates), and share the ability to release nitric oxide or nitric oxide related species to cause vasodilatation. The release of nitric oxide requires nonenzymic or enzymic breakdown of the nitrates, and so these drugs are often referred to as indirect nitric oxide donors. Non-enzymic release of nitric oxide from organic nitrates requires the presence of thiols (also called sulphydryl groups or RSH). This reaction can form either nitric oxide or inorganic nitrite ${ }^{34}$ and only a few thiol- containing compounds will cause the in-vivo release of nitric oxide and activation of guanylyl cyclase. Of these, $\mathrm{N}$-acetylcysteine and cysteine are the best known. The release of nitric oxide from organic nitrates may occur via the formation of S-nitrothiols as intermediates. Enzymic breakdown of organic nitrates may also cause nitric oxide release at the site of action, but the identity and action of these enzymes remains unclear.

The thiol requirement for nitric oxide release may explain the phenomenon of nitrate tolerance. Long term treatment with organic nitrates causes a marked attenuation in most of their pharmacological effects, which can be reversed with a nitrate-free interval. ${ }^{35}$ This may be due to a depletion of intracellular thiol groups which are replaced during the nitrate-free interval. However, studies have failed to show intravascular or plasma thiol depletion in nitrate tolerance, and studies in which additional $\mathrm{N}$-acetylcysteine has been given have produced conflicting results. Several compounds which are a combination of an organic nitrate and a cysteine moiety (organic nitrate esters) have been developed to overcome the problem, and seem to avoid the tolerance seen with organic nitrates. ${ }^{36}$ These compounds are not yet available clinically.

A variant of tolerance has been seen in workers chronically exposed to high levels of organic nitrates (in the explosives industries) who have developed angina or myocardial infarction when the exposure ceased. A similar effect is seen on abrupt withdrawal of inhaled nitric oxide, where there is sometimes a rebound pulmonary hypertension and hypoxia. ${ }^{37}$ Both of these may be due to suppression of endogenous nitric oxide production by exogenous sources. Nitric oxide is known to inhibit its own production by an effect on the metallo-protein portion of nitric oxide synthase, and by altering arginine uptake into cells via the $y+$ cationic amino acid transport system.

In anaesthetic practice organic nitrates are widely used for treatment of and prophylaxis against perioperative myocardial ischaemia. At low doses glyceryl trinitrate is a venodilator, but in higher doses arteriolar dilatation occurs, and so the drug can be used as a hypotensive agent. Pulmonary hypertension can be treated with organic nitrates, although they show no selectivity and so systemic hypotension may occur, and any intrapulmonary ventilation/perfusion mismatch will be worsened.

\section{Sodium nitroprusside}

Sodium nitroprusside is a member of the iron nitrosyl group of nitric oxide donors. It was synthesised in 1850 , first used clinically in 1928 , but was not released as a commercially available product until 1974 because 
of concerns about toxicology and difficulties in the manufacturing process. ${ }^{38}$ Chemically it is composed of five cyanide moieties and a nitrosyl group round a ferrous ion centre. It is a "direct" nitric oxide donor, releasing nitric oxide without enzymic action or thiol groups. This usually occurs with an interaction with oxyhaemoglobin, resulting in cyanide, nitric oxide and methaemoglobin, but photolysis can occur ex-vivo and so sodium nitroprusside solutions are kept shielded from light. The breakdown product that concerns clinicians is the cyanide. Some of this binds to the methaemoglobin to form cyanomethaemoglobin. This is not toxic, and remains in equilibrium with free cyanide. The free cyanide is gradually cleared by conversion to thiocyanate in the liver, where a cyanide specific enzyme in mitochondria, thiosulphate transferase, combines cyanide with sulphur derived from intracellular thiosulphate, which is excreted renally. The treatment of cyanide toxicity therefore involves increasing methaemoglobin levels using sodium nitrite, and giving additional thiosulphate.

Sodium nitroprusside by intravenous infusion produces rapid veno- and arteriolar vasodilatation, an effect is seen in $30 \mathrm{sec}$, and the drug action stops two to three minutes after stopping the infusion. This results in reduced left ventricular afterload, leading to hypotension, usually accompanied by a reflex tachycardia. Cardiac output can increase, decrease or stay the same depending on ventricular preload before the infusion started. ${ }^{38}$ The rapid action of sodium nitroprusside, its potency and the ability to rapidly manipulate the blood pressure by altering the infusion rate means it has been used to treat all forms of hypertensive emergencies, and to induce intraoperative hypotension. The combined effect of pre- and afterload reduction also led to the drug being used to treat cardiac failure after myocardial infarction, ${ }^{39}$ although this was largely abandoned due to emerging concern about coronary "steal," and the demonstration of a greater benefit with glyceryl trinitrate.

Tolerance does not develop with sodium nitroprusside in the same way that it does with organic nitrates, although prolonged therapy is usually avoided because of concerns over cyanide toxicity. Rebound hypertension may occur with abrupt cessation of treatment, the mechanisms may be similar to those occurring with abrupt cessation of inhaled nitric oxide, although increased plasma renin levels may also account for this effect. The worsening of ventilation/perfusion matching within the lungs is a well recognised side effect of treatment.

\section{Other nitric oxide dependent vasodilators}

Local production of nitric oxide by endothelial cells can be stimulated by infusions of acetylcholine, bradykinin, adenosine, calcitonin gene related peptide, substance $P$, and other mediators. Of these only two have been used clinically. Although the physiological role of acetylcholine induced nitric oxide release remains unclear ${ }^{9}$ it is the standard method to induce endothelial nitric oxide production in the laboratory. Acetylcholine infusions have been studied in patients with chronic obstructive lung disease $\mathrm{A}^{\mathbf{0}}$ and pulmonary hypertension. ${ }^{41}$ In both cases pulmonary vasodilatation occurred, but because the half-life of acetylcholine is longer than the lung-systemic circulation time, systemic vasodilatation also occurred. In addition, in common with all systemic vasodilators, ventilation/perfusion mismatching increased and the arterial oxygen tension decreased.

Adenosine stimulates purine receptors on both endothelial and smooth muscle cells. The receptors on the endothelial cells cause smooth muscle relaxation by nitric oxide release, the receptors on the smooth muscle cells may act directly. Adenosine infusions have also been studied in patients with pulmonary hypertension ${ }^{42}$ and heart failure. Adenosine showed some selectivity for the pulmonary circulation, probably because of the short half life of the drug (about nine seconds) resulted in a lower dose being presented to the systemic circulation, although the problem of ventilation/perfusion mismatching remains. In the doses used the expected changes in heart rhythm did not occur.

Nitric oxide is produced from $\mathrm{L}$-arginine, so increasing the substrate available might increase the nitric oxide produced. Several studies on volunteers have shown minimal effects, probably because cNOS activity is not limited by intracellular arginine concentrations. Endothelial cells seem to maintain arginine concentrations by recycling citrulline back to arginine, and by taking up arginine via the $y+$ transporter system. However, in experimental situations where iNOS is induced, vascular tissue relaxation becomes arginine dependent, ${ }^{43}$ because of increased arginine requirements and possibly also because the inducible isoform requires higher arginine concentrations. The clinical usefulness of this observation is unclear.

The conversion of arginine to nitric oxide involves an intermediate compound, hydroxyarginine. The conversion of hydroxyarginine to nitric oxide can occur without nitric oxide synthase, probably via one of the cytochrome P450 enzymes. ${ }^{44}$ However, the total effect of hydroxyarginine on nitric oxide production may be unpredictable, as it competes with arginine for arginase and for the cationic transporters, so modulating arginine availability. When the tissue-specific effects of hydroxyarginine have been determined it may provide the basis for a new class of nitric oxide donors. 
This brief review provides an overview of nitric oxide mediated vasodilatation. Many other endogenous substances are also highly vasoactive, for more details of these and nitric-oxide mediated effects readers are referred to an excellent review by Searle and Sahab in this Journal, ${ }^{9}$ and several other general and specific reviews. ${ }^{38,45,46}$

\section{References}

1 Bonner FT, Stedman G. The chemistry of nitric oxide and redox-related species. In: Feelisch M, Stamler JS (Eds.). Methods in Nitric Oxide Research, lst ed. Chichester: John Wiley and Sons Ltd., 1996: 3-27.

2 Gibson $Q H$, Roughton FJW. The kinetics and equilibria of the reactions of nitric oxide with sheep haemoglobin. J Physiol (Lond) 1957; 136: 507-26.

3 Clutton-Brock J. Two cases of poisoning by contamination of nitrous oxide with higher oxides of nitrogen during anaesthesia. Br J Anaesth 1967; 39: 388-92.

4 Meyer $M$, Piiper $J$. Nitric oxide (NO), a new test gas for study of alveolar-capillary diffusion. Eur Respir J 1989; 2: 494-6.

5 Furchgott RF, Zawadzki JV. The obligatory role of endothelial cells in the relaxation of arterial smooth muscle by acetylcholine. Nature $1980 ; 288$ : 373-6.

6 Arnold WP, Aldred R, Murad F, et al. Cigarette smoke activates guanylate cyclase and increases guanosine $3^{\prime}, 5^{\prime}$-monophosphate in tissues. Science 1977; 198: 934-6.

7 Ignarro LJ, Buga GM, Wood KS, Byrns RE, Chaudhuri $G$. Endothelium-derived relaxing factor produced and released from artery and vein is nitric oxide. Proc Natl Acad Sci USA 1987; 84: 9265-9.

8 Palmer RMJ, Ferrige AG, Moncada S. Nitric oxide release accounts for the biological activity of endothelium-derived relaxing factor. Nature 1987; 327: 524-6.

9 Searle NR, Sahab P. Endothelial vasomotor regulation in health and disease. Can J Anaesth 1992; 39: 838-57.

10 Drexler $H$, Zeiber $A M$, Wollschläger $H$, Meinertz $T$, Just $H$, Bonzel $T$. Flow-dependent coronary artery dilatation in humans. Circulation 1989; 80: 466-74.

11 Boulanger $C$, Lüscher TF. Release of endothelin from the porcine aorta. Inhibition by endothelium- derived nitric oxide. J Clin Invest 1990; 85: 587-90.

12 Bassenge E. Antiplatelet effects of endothelium-derived relaxing factor and nitric oxide donors. Eur Heart J $1991 ; 12$ : 12-5.

13 Garthwaite J, Charles SL, Chess-Williams $R$. Endothelium-derived relaxing factor release on activation of NMDA receptors suggests role as intercellular messenger in the brain. Nature 1988; 336: 385-8.

14 Kaiser $M G$, During $M J$. Combining laser doppler flowmetry with microdialysis: a novel approach to investi- gate the coupling of regional cerebral blood flow to neuronal activity. J Neurosci Methods 1995; 60: 165-73.

15 Wang $Q$ Kjaer $T$, Jorgensen $M B$, et al. Nitric oxide does not act as a mediator coupling cerebral blood flow to neural activity following somatosensory stimuli in rats. Neurol Res $1993 ; 15$ : 33-6.

16 Hollocher TC, Hibbs JB Jr. Enzymes of bacteria, plants and fungi that process free nitrogen oxides. In: Feelisch M, Stamler JS (Eds.). Methods in Nitric Oxide Research. Chichester: John Wiley and Sons Ltd, 1996: 119-46.

17 De Groote MA, Fang FC. NO inhibitions: antimicrobial properties of nitric oxide. Clin Infect Dis 1995; 21 : S162-5.

18 Schoedon $G$, Schneemann $M$, Walter $R$, Blau $N$, Hofer $S$, Schaffner $A$. Nitric oxide and infection: another view. Clin Infect Dis 1995; 21: S152-7.

19 Wong $H R$, Carcillo JA, Burckart G, Kaplan SS. Nitric oxide production in critically ill patients. Arch Dis Child 1996; 74: 482-9.

20 Pepke-Zaba J, Higenbottam TW, Dinh-Xuan AT, Stone $D$, Wallwork J. Inhaled nitric oxide as a cause of selective pulmonary vasodilatation in pulmonary hypertension. Lancet 1991; 338: 1173-4.

21 Snow DJ, Gray SJ, Ghosh S, et al. Inhaled nitric oxide in patients with normal and increased pulmonary vascular resistance after cardiac surgery. $\mathrm{Br}$ J Anaesth 1994; 72 : 185-9.

22 Girard C, Lehot J-J, Pannetier J-C, Filley S, Ffrench $P$, Estanove $S$. Inhaled nitric oxide after mitral valve replacement in patients with chronic pulmonary artery hypertension. Anesthesiology 1992; 77: 880-3.

23 Allman KG, Young JD, Carapiet D, Stevens JE, Ostman-Smith I, Archer LNJ. Effects of oxygen and nitric oxide in oxygen on pulmonary arterial pressures of children with congenital cardiac defects. Pediatr Cardiol 1996; 17: 246-50.

24 Roberts JD Jr, Lang P, Bigatello LM, Vlahakes GJ, Zapol $W M$. Inhaled nitric oxide in congenital heart disease. Circulation 1993; 87: 447-53.

25 Frostell CG, Blomqvist $H$, Hedenstierna G, Lundberg J, Zapol WM. Inhaled nitric oxide selectively reverses human hypoxic pulmonary vasoconstriction without causing systemic vasodilation. Anesthesiology 1993; 78: 427-35.

26 Weir EK, Archer SL. The mechanism of acute hypoxic pulmonary vasoconstriction: the tale of two channels. FASEB J 1995; 9: 183-9.

27 Kinsella JP, Neish SR, Shaffer E, Abman SH. Low-dose inhalation nitric oxide in persistent pulmonary hypertension of the newborn. Lancet 1992; 340: 819-20.

28 Roberts JD, Polaner DM, Lang P, Zapol WM. Inhaled nitric oxide in persistent pulmonary hypertension of the newborn. Lancet 1992; 340: 818-9. 
29 Rossaint R, Falke KJ, López F, Slama K, Pison U, Zapol $W M$. Inhaled nitric oxide for the adult respiratory distress syndrome. N Engl J Med 1993; 328: 399-405.

30 Wysocki $M$, Delclaux $C$, Roupie $E$, et al. Additive effect on gas exchange of inhaled nitric oxide and intravenous almitrine bismesylate in the adult respiratory distress syndrome. Intensive Care Med 1994; 20: 254-9.

31 Radermacher P, Huet $\Upsilon$, Pluskwa F, et al. Comparison of ketanserin and sodium nitroprusside in patients with severe ARDS. Anesthesiology 1988; 68: 152-7.

32 Melot C, Naeije R, Mols $P$, Hallemans $R$, Lejeune P, Jaspar $N$. Pulmonary vascular tone improves pulmonary gas exchange in the adult respiratory distress syndrome. Am Rev Respir Dis 1987; 136; 1232-6.

33 Murrell $W$. Nitro-glycerine as a remedy for angina pectoris. Lancet $1879 ; 1: 80-1$.

34 Feelisch $M$, Noack E, Scbröder $H$. Explanation of the discrepancy between the degree of organic nitrate decomposition, nitrite formation and guanylate cyclase stimulation. Eur Heart J 1988; 9: 57-62.

35 Parker JO, Isosorbide-5-mononitrate study group. Eccentric dosing with isosorbide-5-mononitrate in angina pectoris. Am J Cardiol 1993; 72: 871-6.

36 Kojda $G$, Noack $E$. Nitric oxide liberating, soluble guanylate cyclase stimulating and vasorelaxing properties of the new nitrate-compound SPM 3672. J Cardiovasc Pharmacol 1993; 22: 103-11.

37 Miller OI, Tang SF, Keech A, Celermajer DS. Rebound pulmonary hypertension on withdrawal from inhaled nitric oxide. Lancet 1995; 346: 51-2.

38 Friederich JA, Butterworth JF. Sodium nitroprusside: twenty years and counting. Anesth Analg 1995; 81 : 152-62.

39 Franciosa JA, Guiba NH, Limas CJ, Rodriguera E, Cobn $J N$. Improved left ventricular function during nitroprusside infusion in acute myocardial infarction. Lancet 1972; 1: 650-4.

40 Adnot $S$, Kouyoumdjian $C$, Defouilloy $C$, et al. Hemodynamic and gas exchange responses to infusion of acetylcholine and inhalation of nitric oxide in patients with chronic obstructive lung disease and pulmonary hypertension. Am Rev Respir Dis 1993; 148: 310-6.

41 Palevsky HI, Lang W, Crow J, Fishman AP. Prostacyclin and acetylcholine as screening agents for acute pulmonary vasodilator responsiveness in primary pulmonary hypertension. Circulation 1990; 82: 2018-26.

42 Morgan JM, McCormack DG, Griffiths MJD, Morgan CJ, Barnes PJ, Evans TW. Adenosine as a vasodilator in primary pulmonary hypertension. Circulation 1991; 84: 1145-9.

43 Allman KG, Stoddart AP, Kennedy $M M$, Young JD. Larginine augments nitric oxide production and mesen- teric blood flow in ovine endotoxemia. Am J Physiol 1996; 271: H1296-301.

44 Schott CA, Bogen CM, Vetrovsky P, Berton CC, Stoclet $J C$. Exogenous $N^{G}$-hydroxyl-L-arginine causes nitrite production in vascular smooth muscle cells in the absence of nitric oxide synthase activity. FEBS Lett 1994; 341: 203-7.

45 Calver $A$, Collier J, Vallance $P$. Nitric oxide and cardiovascular control. Exp Physiol 1993; 78: 303-26.

46 Kam PCA, Govender G. Nitric oxide: basic science and clinical applications. Anaesthesia 1994; 49: 515-21. 
Dr J.D. Young



E monoxyde d'azote (NO) a été découvert en 1648 et ses propriétés chimiques identifiées en 1772 par Joseph Priestley' qui l'appela «air nitreux» (nitrous air). C'est lui qui a décrit sa réaction avec l'air (common air) pour former le dioxyde d'azote $\left(\mathrm{NO}_{2}\right)$. Depuis, la chimie du NO a fait l'objet de recherches intensives étant donné que le NO est utilisé pour la production inductrielle de l'acide nitrique et que c'est aussi un important polluant de l'environnement. Comme c'est un sous-produit du métabolisme microbien et comme il a une grande affinité pour les métalloprotéines comme l'hémoglobine, les biologistes s'intéressent depuis longtemps au NO. ${ }^{2}$ L'exposition accidentelle au NO à l'état gazeux gazeux a été rapportée dans l'industrie, les mines et l'agriculture. En 1966, l'attention des anesthésistes était attirée par deux cas d'intoxication causée par l'inhalation de hautes concentrations de NO occasionnées par la contamination de la source de protoxyde d'azote. ${ }^{3}$ Le NO était utilisé en clinique pour la première fois en remplacement du monoxyde de carbone pour la mesure de la capacité de diffusion pulmonaire ${ }^{4}$ parce que sa réaction cinétique avec l'hémoglobine était plus rapide, ce qui permettait de mesurer la vraie capacité de diffusion pulmonaire.

La découverte du NO endogène est attribuée à Furchgott et Zawadzki ${ }^{5}$ qui avaient observé que les anneaux vasculaires préalablement contractés avec de la noradrénaline se relâchaient au contact de l'acétylcholine seulement si leur endothélium vasculaire demeurait intact. Ceci signifiait que l'acétylcholine déclenchait la libération, à partir de l'endothélium, d'un facteur dont la diffusion dans les cellules musculaires lisses provoquait la relaxation du muscle lisse. Cette substance, une molécule éphémère des systèmes biologiques, était appelée EDRF (endothelium derived relaxing factor). Bien que l'action vasodilatatrice du NO à l'état gazeux ait été connu depuis longtemps, ${ }^{6}$ ce n'est qu'en 1987 que deux groupes démontraient indépendamment que l'EDRF et le NO étaient en réalité la même substance. ${ }^{7,8}$ Depuis lors, on a assisté à la prolifération de la recherche sur le NO et, pendant les neuf dernières années, le nombre de références à son sujet a progressé de façon logarithmique. On reconnaît maintenant l'intervention du NO dans le contrôle vasculaire, la neurotransmission, la fonction

\section{Le monoxyde d'azote et ses congénères}

immunitaire, la lésion de reperfusion et dans plusieurs autres fonctions biologiques.

\section{Mécanismes d'action}

Le NO est une molécule lipophile hautement diffusible. Lorsque libéré par les cellules endothéliales, il passe aux cellules musculaires lisses sous-jacentes et se lie au groupe hème de la guanylate cyclase, stimulant la conversion de la GTP cyclique (le triphosphate cyclique de guanosine) en GMP cyclique (le monophosphate cyclique de guanosine). Ceci a pour effet de réduire la concentration du calcium intramusculaire en modulant l'activité des canaux calciques et la libération de calcium à partir du réticulum sarcoplasmique, provoquant ainsi la relaxation du muscle lisse ${ }^{9}$ et, de là, la vasodilatation. Le NO est produit à partir de la L-arginine et de l'oxygène moléculaire par une famille d'enzymes appelée synthases du NO (NOS), qui sont de structure identique au cytochrome P450. Il existe deux isoformes constitutives responsables du débit basal de NO dans les cellules endothéliales et autres cellules (ecNOS et ncNOS ou simplement $\mathrm{cNOS}$ ), et une forme qui n'est produite qu'après stimulation cellulaire par les cytokines, l'isoforme inductible (iNOS). Les enzymes constitutifs sont importants pour la régulation du tonus vasculaire basal, l'isoforme inductible pourrait avoir une activité antimicrobienne et l'excès de NO produit par cet enzyme peut expliquer la vasodilatation qu'on rencontre dans le choc septique.

Les humains produisent environ $1 \mathrm{mM}$ de métabolites du NO par jour. La plus grande partie de ce NO provient vraisemblablement de sa libération continue à partir des cellules endothéliales, ce qui permet la modulation des résistances pulmonaires et vasculaires systémiques. Il s'agit là un mécanisme probable de contrôle local. La contrainte provoquée par le cisaillement sur la paroi vasculaire augmente parallèlement à l'augmentation du débit artériel. Ceci constitue un stimulus puissant pour la production de NO, qui dilate le vaisseau pour s'accommoder à l'augmentation du débit. ${ }^{9}$ Ceci peut être particulièrement important pour la circulation coronaire, ${ }^{10}$ le débit coronaire pouvant varier considérablement sur une courte période de temps. Le NO peut aussi agir en harmonie avec l'endothéline, un vasoconstricteur puissant dérivé de l'endothélium. L'augmentation de la GMP cyclique, un effet de l'activation du NO par la 
guanylate cyclase, provoque une diminution de la synthèse d'endothéline et, de là, une vasodilatation plus intense. ${ }^{11}$ L'agrégation des plaquettes libère du NO et de la prostacycline qui ont deux effets majeurs. Ces deux médiateurs inhibent l'agrégation additionnelle des plaquettes et provoquent une vasodilatation locale qui augmente le flux sanguin local. ${ }^{12}$ Ce contrôle de rétroaction négatif peut représenter un des mécanismes de la prévention des thromboses intravasculaires.

Le NO est aussi un neurotransmetteur postsynaptique produit au moment de l'activation des récepteurs du glutamate, ${ }^{13}$ produisant la fois des effets centraux et des effets périphériques. Le NO serait le neurotransmetteur du système nerveux NANC (non adrénergique non cholinergique) qui innerve les viscères abdominaux, les voies respiratoires et d'autres organes. Le NO est aussi un neurotransmetteur du système nerveux central, et pourrait être important pour la mémoire et le lien de l'activité neuronale avec le débit sanguin cérébral local ${ }^{14,15}$ bien que ce soit pas encore prouvé.

On ne sait trop pourquoi les mammiferes possèdent un système inductible de la $\mathrm{NO}$ activé par les cytokines mais il semble ce système peut contribuer aux mécanismes de défense de l'hôte. Il a été démontré que le haut débit de NO produit par la iNOS était cytotoxique pour un grand nombre de pathogènes intracellulaires. ${ }^{7}$ La concentration de NO peut ne pas être suffisamment élevée pour être cytotoxique mais le peroxynitrite, produit par le superoxyde et le NO, peut avoir un effet cytotoxique encore plus important. On connaît pas l'importance clinique de cet effet chez l'humain. ${ }^{17,18}$ Plusieurs autres espèces cytotoxiques sont aussi produites par les macrophages incluant l'ion hypochlorite et les radicaux hydroxyles. Bien que la concentration de NO augmente pendant le sepsis chez l'humain, cette augmentation n'est jamais aussi dramatique que celle qu'on rencontre chez les rongeurs infectés. ${ }^{19}$

\section{Le monoxyde d'azote en clinique}

En 1991, Peke-Zaba et al publiaient le premier compterendu sur l'utilisation du NO comme vasodilatateur pulmonaire. ${ }^{21}$ Ces auteurs avaient observé huit patients souffrant d'hypertension pulmonaire grave. L'inhalation de 40 parties par million (ppm) de NO a diminué la résistance pulmonaire vasculaire chez tous ces patients d'environ 1120 dynes $\cdot \mathrm{sec} \cdot \mathrm{cm}^{-5}$ à environ 800 dynes $\mathrm{sec} \cdot \mathrm{cm}^{-5}$ (normale $<150$ dynes.sec. $\mathrm{cm}^{-5}$ ). Une perfusion de prostacycline produisait le même effet chez six des huit patients mais provoquait en même temps une réduction de la résistance vasculaire systémique d'environ 1900 dynes $\cdot \mathrm{sec} \cdot \mathrm{cm}^{-5}$ à 1500 dynes $\cdot \mathrm{sec} \cdot \mathrm{cm}^{-5}$ (normale entre 1000 et 2000 ). Donc l'inhalation de NO produisait un vasodilatation pulmonaire sélective. C'est l'action du NO sur la surface abluminale (externe) des vaisseaux pulmonaires de résistance qui provoque la vasodilatation. Tout le NO largué dans la circulation est immédiatement inactivé en réagissant avec l'oxyhémoglobine pour former de la methémoglobine et du nitrate inorganique. Comme le nitrate inorganique (contrairement aux nitrates organiques) n'est pas vasoactif, il y a absence d'effets systémiques directs. Des résultats identiques ont été obtenus chez des patients souffrant d'hypertension pulmonaire causée par une valvulopathie mitrale ${ }^{21,22}$ et une maladie cardiaque congénitale. ${ }^{23,24}$ Dans toutes ces études, on a constaté une diminution significative de la résistance vasculaire pulmonaire mais, cliniquement cette réduction était modeste, et la résistance vasculaire demeurait amplement élevée pendant l'inhalation de NO. Par contre, des observations réalisées chez des volontaires dont l'hypertension pulmonaire était induite par hypoxie ${ }^{25}$ ont montré que le NO abolissait totalement la vasoconstriction pulmonaire. L'inhalation de NO n'a pas d'effet sur les vaisseaux pulmonaires normaux. On peut s'attendre à de tels résultats parce que la vasoconstriction pulmonaire aiguë est causée par la contraction du muscle lisse alors que dans l'hypoxie, elle est semble-t-il, déclenchée par des changements de la réaction d'oxyréduction des cellules qui altèrent indirectement la concentration intracellulaire de calcium. ${ }^{26}$ Les effets du NO sur le calcium intracellulaire neutralisent cette réaction. Dans l'hypertension pulmonaire chronique, la plus grande partie de l'augmentation de la résistance vasculaire pulmonaire est due à la déposition dans l'adventice de protéines matricielles non distensibles et ne peut être affectée par un vasodilatateur.

Pendant la vie foetale, la vasoconstriction pulmonaire maintient la résistance pulmonaire vasculaire élevée. Ceci a pour effet d'augmenter les pressions du côté droit de la circulation et de favoriser un shunt droit-gauche à travers le foramen ovale et le ductus artériosus. Après la naissance, la résistance pulmonaire diminue subitement et le foramen oval se ferme lorsque la pression auriculaire gauche dépasse la pression auriculaire droite. Le ductus artériosus se ferme aussi et le shunt droit-gauche est aboli. Cependant, chez quelques nouveau-nés, la résistance vasculaire pulmonaire ne baisse pas (persistance de la circulation foetale). Ces enfants ont des shunts droit-gauche permanents et de l'hypoxémie qui sont très difficiles à traiter. Par contre, le shunt augmente l'acidose et l'hypoxie associées et tend à prévenir la fermeture du canal artériel et à augmenter la résistance pulmonaire vasculaire. Ceci aggrave le shunt encore plus. Dans ces circonstances, l'agent thérapeutique idéal serait un vasodilatateur pulmonaire sélectif, étant donné que 
les pressions du côté gauche doivent être maintenues pendant que celles du côté droit sont réduites. Dans le même numéro du Lancet de 1992, deux groupes publiaient des comptes rendus sur l'utilisation du NO chez ces enfants. ${ }^{27,28}$ L'effet sur l'oxygénation artérielle était dramatique, la $\mathrm{PaO}_{2}$ augmentant de 3 à 5 fois. Il existe des données non publiées provenant d'une étude aléatoire contrôlée de grande envergure (étude NINOS) qui montre que l'inhalation de NO diminue la nécessité d'utiliser un oxygénateur extracorporel à membrane (ECMO) chez ces enfants.

L'ajout de NO au gaz inspiré de patients ventilés mécaniquement pour insuffisance respiratoire aiguë diminue la résistance vasculaire pulmonaire. Cependant, ce qui frappe le plus c'est l'augmentation immédiate de l'oxygénation artérielle. Ceci a d'abord été rapporté sur une série de patients par Rossaint $e t$ al. ${ }^{29}$ dont l'étude révélait une amélioration moyenne de $47 \mathrm{mmHg}$ $(6,2 \mathrm{kPa})$ du rapport $\mathrm{PaO}_{2} / \mathrm{FIO}_{2}$ et une réduction de $4 \%$ de la fraction de shunt. Des mesures simultanées avec la technique de l'élimination de multiples gaz inertes (MIGET) ont montré que cet effet était du à l'amélioration du rapport ventilation/perfusion.

Cette amélioration s'explique par le fait que le NO n'atteint que les régions ventilées du poumon et, ainsi, améliore sélectivement la perfusion des régions bien ventilées au dépend des régions mal ventilées. Le débit sanguin est donc mieux harmonisé avec la ventilation. Si on administre en même temps un vasoconstricteur systémique, la vasoconstriction les régions mal ventilées sera plus intense mais le NO inhibera la vasoconstriction des régions bien ventilées et procurera ainsi un supplément d'oxygène. ${ }^{30}$ L'inverse survient quand des vasodilatateurs systémiques sont administrés à des insuffisants respiratoires aigus. La vasoconstriction hypoxique pulmonaire normale des régions mal ventilées et l'inégalité du rapport ventilation/perfusion s'aggravent. ${ }^{31,32} \mathrm{Ceci}$ a conduit à l'adoption du NO comme traitement du syndrome de détresse respiratoire de l'adulte dans plusieurs pays, bien qu'aucune étude aléatoire n'ait jusqu'à maintenant prouvé de bénéfices autres que l'amélioration de l'oxygénation artérielle.

\section{Les donneurs de monoxyde d'azote}

Il existe au moins 30 classes de donneurs de NO, parmi lesquels seulement deux (les nitrates organiques et le nitroprussiate de sodium) sont utilisés couramment en clinique.

\section{La nitroglycérine}

La nitroglycérine a été synthétisée en 1846 et sa première utilisation sublinguale (le trinitrate de glycéryl, (TNG)) dans l'angine était rapportée par Murrell en
1879.33 Celui-ci avait déduit que ce médicament pouvait avoir une action identique à celle du nitrite d'amyl en inhalation, une substance connue comme antiangineuse par Brunton depuis 1857. Depuis ce temps, le TNG a constitué la pierre angulaire de la thérapie anti-angineuse bien que le dinitrate d'isosorbide, le mononitrate-5 d'isosorbide et le tétranitrate d'érythrityl aient été introduits à cause de leur plus longue durée d'action pour la prévention de la crise d'angor.

Ces produits sont des esters polyol du NO (communément appelés nitrates organiques) et ils libèrent tous du NO ou un vasodilatateur apparenté. La libération de NO nécessite la dégradation non enzymatique des nitrates et c'est la raison pour laquelle on appelle ces médicaments donneurs "indirects" de NO. La libération non enzymatique de NO à partir des nitrates organiques se fait en présence de thiols (aussi appelés groupes sulphydryl ou RSH). Cette réaction peut former soit du NO soit du nitrite inorganique ${ }^{34}$ et seulement quelques-uns des composés contenant du thiol entraînent la libération in vivo de NO et l'activation de la guanylate cyclase. De ces composés, les mieux connus sont la $\mathrm{N}$-acétylcystéine et la cystéine. La libération de NO à partir des nitrates organiques peut survenir par l'intermédiaire des S-nitrosothiols formés dans le plasma. La dégradation locale enzymatique des nitrates organiques peut aussi provoquer la libération de NO mais l'identité et l'action de ces enzymes sont mal connues.

Le besoin de thiol pour la libération du NO peut expliquer le phénomène de la tolérance au nitrate. Le traitement à long terme avec les nitrates organiques provoque souvent une forte diminution de la plupart de leurs effets pharmacologiques qu'il est possible de renverser en cessant l'administration du médicament. ${ }^{35} \mathrm{Cet}$ effet serait dû à la déplétion intracellulaire des groupes thiols qui sont régénérés pendant l'intervalle libre de nitrates. Cependant, des études n'ont pas réussi à démontrer la déplétion du thiol intravasculaire ou plasmatique pendant la tolérance aux nitrates, et d'autres au cours desquelles de $\mathrm{N}$-acétylcystéine additionnelle avait été administrée ont donné des résultats contradictoires. Plusieurs composés de nitrate organique et d'un fragment moléculaire de la cystéine (les esters nitrates organiques) ont été développés pour résoudre ce problème et il semble qu'ils peuvent protéger de la tolérance survenant pendant l'administration prolongée les nitrates organiques. ${ }^{36}$ Ces produits ne sont pas disponibles en clinique à l'heure actuelle.

Une variation de cette tolérance se rencontre chez les travailleurs exposés chroniquement à des niveaux élevés de nitrates organiques (dans l'industrie des explosifs) qui développent de l'angor ou un infarctus du myocarde 
quand cette exposition cesse. De la même façon, l'arrêt subit de l'inhalation de NO est parfois suivi d'une hypertension pulmonaire et d'une hypoxie de rebondissement. ${ }^{37}$ Dans ces deux cas, la réaction serait causée par la suppression de la production endogène de NO par des sources exogènes. Le NO est connu comme un autoinhibiteur par son activité sur la portion métallo-protéinique de la NO synthase et par l'altération du captage cellulaire via le système de transport de l'amino acide y+ cationique.

En anesthésie, les nitrates organiques sont largement utilisés pour le traitement et la prophylaxie de l'ischémie myocardique périopératoire. À faible dose, le trinitrate de glycéryl n'est pas un vénodilatateur mais à dose plus élevée, il produit une dilatation artériolaire de sorte que ce médicament peut aussi être utilisé comme agent hypotenseur. Malgré leur manque de sélectivité, les nitrates organiques peuvent être administrés dans l'hypertension pulmonaire mais ils est possible qu'ils provoquent de l'hypotension systémique et aggravent la perturbation du rapport ventilation/perfusion.

\section{Le nitroprussiate de sodium}

Le nitroprussiate de sodium fait partie du groupe nitrosyl ferreux des donneurs de NO. Il a été synthétisé en 1850 , utilisé en clinique pour la première fois en 1928 , mais n'a été commercialisé qu'en 1974 parce qu'on le croyait toxique et qu'il était difficile à fabriquer. ${ }^{38}$ Chimiquement, il est composé de cinq fragments moléculaires de cyanure et d'un groupe nitrosyl autour d'un noyau ionique ferreux. Comme il libère le NO sans l'intermédiaire d'enzymes ou du groupe thiol, il est considéré comme un donneur "direct» de NO. Son interaction avec l'oxyhémoglobine produit du cyanure, du NO et de la methémoglobine mais une photolyse peut survenir ex vivo, et, pour cette raison, le nitroprussiate de sodium doit être conservé à l'abri de la lumière. Le cyanure est le produit de dégradation qui intéresse les cliniciens. Une partie du cyanure se lie à la methémoglobine pour former la cyanmethémoglobine. Ce produit non toxique demeure en équilibre avec le cyanure libre. Le cyanure libre est éliminé graduellement par conversion en thiocyanate au foie où, dans les mitochondries, une enzyme spécifique au cyanure, la thiosulfate transférase, combine le cyanure avec le souffre dérivé du thiosulfate intracellulaire pour être excrété par le rein. Le traitement de la toxicité au cyanure nécessite l'augmentation des concentrations de methémoglobine à l'aide du nitrite de sodium et l'administration supplémentaire de thiosulfate.

La perfusion intraveineuse de nitroprussiate de soude produit une vasodilatation veineuse et artériolaire rapide, un effet visible en 30 secondes, et l'action cesse deux ou trois minutes après l'arrêt de la perfusion. Une diminu- tion de la postcharge ventriculaire gauche suit avec de l'hypotension ordinairement accompagnée d'une tachycardie réflexe. Le débit cardiaque peut augmenter, diminuer ou demeurer le même selon la condition de la précharge ventriculaire avant le début de la perfusion. ${ }^{38}$ L'action rapide du nitroprussiate de sodium, sa puissance et sa capacité de faire varier rapidement la pression artérielle en altérant sa vitesse de perfusion favorisent son utilisation dans toutes les formes d'urgences hypertensives et aussi pour l'induction de l'hypotension peropératoire délibérée. L'effet combiné de la réduction de la pré- et de la postcharge a été considéré comme un avantage pour le traitement de l'insuffisance cardiaque après l'infarctus du myocarde, ${ }^{39}$ mais ce traitement a été généralement abandonné à cause des difficultés causées par le vol coronaire. De plus, on a démontré que le trinitrate de glycéryl conférait de plus grands avantages.

Avec le nitroprussiate de soude, la tolérance ne se développe pas de la même façon qu'avec les nitrates organiques. Toutefois, la crainte de la toxicité au cyanure limite en général la durée du traitement. L'arrêt subit du traitement peut provoquer de l'hypertension de rebondissement ; le mécanisme de cet effet pourrait être le même que celui qu'entraîne l'arrêt subi de NO en inhalation bien qu'une augmentation de la concentration de la rénine plasmatique puisse l'expliquer. L'aggravation des perturbations du rapport ventilation/perfusion est reconnue comme un effet secondaire du traitement.

Autres pasodilatateurs impliquant le monoxyde d'azote $\mathrm{La}$ production locale de NO par les cellules endothéliales peut être stimulée par des perfusions d'acétylcholine, de bradykinine, d'adénosine, du peptide calcitonine génique, de la substance $P$ et d'autres médiateurs. Parmi ceux-ci, seulement deux ont été utilisés en clinique. Bien que le rôle physiologique de la libération du NO induite par l'acétylcholine demeure obscur, c'est une méthode standard d'induction de la production endothéliale de NO en laboratoire. Les perfusions d'acétylcholine ont été étudiées chez des patients souffrant de maladies pulmonaires obstructives chroniques ${ }^{40}$ et d'hypertension pulmonaire. ${ }^{41}$ Dans les deux cas, une vasodilatation pulmonaire survenait mais comme la demi-vie de l'acétylcholine est plus longue que le temps de circulation pulmonaire systémique, elle s'accompagnait d'une vasodilatation systémique. De plus, comme tous les autres vasodilatateurs systémiques, les perturbations du rapport ventilation/perfusion ont augmenté et la tension artérielle en oxygène a diminué.

L'adénosine stimule les récepteurs de la purine à la fois dans les cellules endothéliales et dans les muscles liss- 
es. Les récepteurs des cellules endothéliales provoquent une relaxation du muscle lisse par libération de NO, mais les récepteurs des cellules du muscle lisse peuvent agir directement. Les perfusions d'adénosine ont aussi été étudiées chez les patients souffrant d'hypertension pulmonaire ${ }^{42}$ et dans l'insuffisance cardiaque. L'adénosine avait un certain degré de sélectivité pour la circulation pulmonaire, probablement à cause de la courte demi-vie du produit (environ $9 \mathrm{sec}$.) avec le résultat qu'une dose moindre atteignait la circulation systémique, mais les perturbations du rapport ventilation/perfusion persistaient. Aux doses utilisées, on n'a pas constaté les changements du rythme cardiaque attendus.

Le NO provient de la $\mathrm{L}$-arginine de sorte que l'augmentation du substrat disponible devrait augmenter sa production. Plusieurs études chez des volontaires ont montré des effets minimes probablement parce que l'activité de la cNOS ne se limite pas aux concentrations intracellulaires d'arginine. Les cellules endothéliales semblent maintenir les concentrations d'arginine en recyclant la citrulline en arginine et par le captage de l'arginine via le système de transporteur $y+$. Cependant, dans des situations expérimentales où la iNOS est induite, la relaxation du tissu vasculaire devient arginine dépendante ${ }^{43}$ par augmentation des besoins en arginine et peut-être aussi à cause parce que l'isoforme inductible requiert des concentrations plus élevées d'arginine. La signification clinique de cette observation demeure obscure.

La conversion de l'arginine en NO nécessite un composé intermédiaire, l'hydroxyarginine. La conversion d'hydroxyarginine en NO peut survenir sans la NO synthase probablement par l'intermédiaire d'un des enzymes du cytochrome P450.44 Cependant, l'effet total de l'hydroxyarginine sur le NO est imprévisible parce qu'elle entre en compétition avec l'arginine pour l'arginase et pour les transporteurs cationiques, ce qui module la disponibilité de l'arginine. Quand les effets tissulaires spécifiques de l'hydroxyarginine seront déterminés, ils fourniront la base d'une nouvelle classe de donneurs de NO.

Cette courte revue résume le rôle du monoxyde d'azote dans la vasodilatation. Plusieurs autres substances endogènes sont aussi fortement vasoactives. Pour connaitre plus en détails les effets obtenus par la médiation du monoxyde d'azote, les lecteurs priés de lire l'excellent article de revue publié par Searle et Sahab dans ce journal, ${ }^{9}$ et plusieurs autres revues générales et spécifiques. ${ }^{38,45,46}$

\section{Références}

(Voir page R27) 